\title{
ОРГАНИ І СЛУЖБИ В СПРАВАХ ДІТЕЙ У СИСТЕМІ ОРГАНІВ ПУБЛІЧНОГО АДМІНІСТРУВАННЯ: ПИТАННЯ ПРАВОСУБ'СКТНОСТІ
}

\section{СТАРИЧЕНКО Алевтина Олександрівна - ад'юнкт Одеського державного університету внутрішніх справ}

DOI 10.32782/LAW.UA.2020.3.14

\begin{abstract}
У статті розглянуто проблеми публічноправових статусів служб у справах дітей при виконання ними функцій у сфері захисту прав дітей в Украйні. Проаналізовано правову основу їхнъої діяльності. Розглянуто основні фуункииі та повноваження служб у справах дітей. Акцентовано увагу на тому, що в Україні служби у справах дітей функиіонують за двома моделями: в системі органів державної виконавчої влади та системі органів місцевого самоврядування. Встановлено, що публічно-правова природа повноважень служб у справах дітей полягає у тому, що вони вступають у правовідносини не від власного імені і не у своӥх інтересах.

З’ясовано, що служби у справах дітей, які не наділені органами місцевого самоврядування статусом юридичної особи, здійснюють свої публічно-правові функиій у сфері ювенальних правовідносин через інші виконавчі органи місиевого самоврядування, як правило через виконавчі комітети.
\end{abstract}

Наявність відомчої вертикалі від місщевої служби у справах дітей до иентрального органу виконавчої влади, що реалізує державну політику у сбері усиновлення та захисту прав дітей, вказує на централізовану діяльність ицх органів, яка перебуває під пильною увагою $i$ контролем держави, та здійснюється у рамках єдиної наиіональної політики у сфері забезпечення прав дітей з регулятивними $i$ контрольними повноваженнями центрального органу.

Ключові слова: дитина, права дитини, захист прав, охорона прав, публічна адміністраціЯ, служба у справах дітей.
Постановка проблеми у загальному вигляді та їі зв'язок із важливими науковими чи практичними завданнями

Захист прав дітей органами публічної адміністрації в Україні належить до важливих завдань правового регулювання держави. До вирішення цієї проблеми залучається ціла низка органів публічної влади та суб’єктів громадського суспільства. Особливе місце серед них займають органи опіки та піклування. Перманентна актуальність правоохоронної діяльності у сфері ювенальних відносин, неоднозначність можливих рішень у кожному конкретному випадку вимагають визначення і уточнення правового статусу органів опіки та піклування та їхнього місця в системі суб'єктів охорони та захисту прав дітей.

Тому дослідження суб'єктів, що здійснюють діяльність у сфері захисту прав дітей, $\epsilon$ корисним та актуальним, що дасть можливість покращити вироблення та реалізацію державної політики у цьому напрямку.

Аналіз останніх досліджень i публікацій, у яких започатковано розв'язання цієї проблеми і на які спирається автор

Огляд наукової літератури свідчить про те, що проблема забезпечення належного державного захисту прав дитини є складовою процесу публічного адміністрування в України та предметом досліджень значної кількості вітчизняних науковців. Однак, незважаючи на попередні теоретичні 


\section{Адміністративне право}

розробки, питання про охорону та захист прав дитини розглядалося більше через такі суб'єкти державної політики у сфері захисту прав дітей, як органи державної виконавчої влади, у той час діяльності органів місцевого самоврядування у цій сфері правовідносин приділяється значно менше уваги. Усі суб'єкти державної політики у сфері захисту прав дітей в умовах сучасного розвитку державності потребують налагодженої, регламентованої на законодавчому рівні взаємодії. Проблеми удосконалення публічного управління у сфері захисту прав дітей в Україні досліджували такі науковці: І.В. Волошина, І.В. Волощук, Ю.В. Губаль, А.В. Дакал, О.М. Дручек, О.Е. Журавель, В.О. Закриницька, Т.Ю. Коваленко, Т.Г. Корж-Ікаєва, Е.В. Костіна, А.М. Кравченко, А.Ф. Кривачук, А.Л. Аабенська, О.О. Мордань, Ю.О. Трестер, О.О. Навроцький, С.Г. Поволоцька, Ж.М. Пустовіт, С.А Саблук, I.В. Швець, О.А. Шульц та ін.

\section{Виділення не вирішених раніше частин загальної проблеми}

Незважаючи на досить широке коло досліджень, присвячених різним аспектам практики функціонування органів публічної адміністрації у сфері захисту прав дітей, питання особливостей їх впливу на формування та реалізацію державної політики щодо захисту прав дітей, службами у справах дітей висвітлені недостатньо, тож потребують подальшого розвитку та поглибленого вивчення.

Відтак метою статті $є$ визначення моделей організації служб у справах дітей у системі органів публічного адміністрування, а також форму їхньої правосуб'єктності у цивільних та адміністративних правовідносинах.

\section{Виклад основного матеріалу}

Із прийняттям 24 січня 1995 р. Закону України «Про органи і служби у справах неповнолітніх та спеціальні установи для неповнолітніх» №20/95-ВР (3 7 лютого 2007 року Закон України «Про органи і служби у справах дітей та спеціальні установи для дітей») [1] були внесені зміни в правовий ста- тус органів опіки та піклування радянського виміру, які поклали початок формуванню нової моделі організації опіки та піклування за дітьми в України.

На сьогодні в Україні проживає понад 7,5 мільйонів дітей, 3 яких понад 70 тисяч дітей-сиріт та дітей, позбавлених батьківських прав, близько 155 тисяч дітей з інвалідністю, 720 тисяч дітей 3 багатодітних та малозабезпечених дітей, 236 тисяч дітей, зареєстрованих як внутрішньо переміщені особи. Таким чином, допомоги держави та контролю за дотриманням їх прав та інтересів потребує 15,5\% дітей [2]. При цьому в національній системі ювенальних органів нині функціонує понад 700 служб у справах дітей. Соціально важливі функції щодо соціального захисту дітей, запобігання дитячій бездоглядності та безпритульності тощо, які виконує служба, зумовлюють необхідність оперативності діяльності та певну самостійність служби у справах дітей від інших державних органів та органів місцевого самоврядування [3].

Відповідно до статті 4 вказаного Закону органи і служби у справах дітей є органами виконавчої влади. Така публічно-правова природа служб вбачається і з приписів пункту 1 Типового положення про службу у справах дітей обласної, Київської та Севастопольської міської державної адміністрації та Типового положення про службу у справах дітей районної, районної у містах Києві та Севастополі державної адміністрації, затверджених постановою Кабінету Міністрів України від 30 серпня 2007 р. №1068, служба у справах дітей обласної, Київської та Севастопольської міської держадміністрації є структурним підрозділом обласної, Київської та Севастопольської міської держадміністрації, який утворюється головою обласної, Київської та Севастопольської міської держадміністрації, підзвітний та підконтрольний відповідно голові обласної, Київської та Севастопольської міської державної адміністрації [4].

У той же час, в окремих територіальних громадах вони перебувають у системі органів місцевого самоврядування [1]. Таким чином, органи і служби у справах дітей можуть формуватися за двома моделями. Перша - в 
структурі органів державної виконавчої влади, друга - в системі виконавчих органів місцевого самоврядування.

У цій ситуації виникає проблема, пов'язана з тим, що одне і те ж повноваження здійснюється органами місцевого самоврядування як власне (самоврядне) повноваження, визначене пунктом 1 частини 2 статті 38 Закону України «Про місцеве самоврядування в Україні» [5], і як повноваження державне, визначене статтею 4 Закону України «Про органи і служби у справах дітей та спеціальні установи для дітей») [1].

Процес укрупнення територіальних громад, що здійснюється в порядку Закону України «Про добровільне об’єднання територіальних громад» [6] та, в основному, завершився виборами до місцевих рад 25 жовтня 2020 року, істотно вплине на практику організаційних моделей досліджуваних суб'єктів, фактично повністю передавши повноваження місцевих органів і служб у справах дітей органам місцевого самоврядування. Більше того, сьогодні визначення курсу децентралізації влади приводить до того, що держава намагається перекласти на органи місцевого самоврядування окрему сферу відповідальності за забезпечення прав дитини. Підтвердженням цієї тези слугує й той факт, що ще під час обговорення питання реалізації Плану заходів першого етапу Національної стратегії реформування системи інституційного догляду та виховання дітей на 2017-2026 роки Уповноважений Президента України 3 прав дитини відзначив, що «основне завдання в умовах децентралізації - збудувати спроможну громаду, яка буде відповідальною за безпеку та благополуччя кожної дитини, яка проживає на їі території, аби діти не відривались від сім’ї і отримали всі необхідні послуги, щоб не потрапити в інтернатні заклади» [7].

3 цього слідує, що реформування структури служб повинно здійснюватися шляхом їхнього створення в усіх без виключення об'єднаних територіальних громадах.

Очевидним є те, що передача повноважень передбачає певну взаємодію між рівнями органів публічної влади та займає певний час для тих органів державної вико- навчої влади районного рівня, що досі реалізують ці повноваження.

Значимість органів та служб у справах дітей у забезпеченні конституційних прав людини випливає 3 приписів статті 51 Конституції України [8], тож в основі їхньої діяльності лежить принцип державного захисту дитинства.

Відповідно до статті 4 Закону України «Про органи і служби у справах дітей та спеціальні установи для дітей» основними завданнями служб у справах дітей є:

розроблення і здійснення самостійно або разом з відповідними органами виконавчої влади, органами місцевого самоврядування, підприємствами, установами та організаціями незалежно від форми власності, громадськими організаціями заходів щодо захисту прав, свобод і законних інтересів дітей;

координація зусиль центральних та місцевих органів виконавчої влади, органів місцевого самоврядування, підприємств, установ та організацій незалежно від форми власності у вирішенні питань соціального захисту дітей та організації роботи із запобігання дитячій бездоглядності;

забезпечення додержання вимог законодавства щодо встановлення опіки та піклування над дітьми, їх усиновлення;

здійснення контролю за умовами утримання i виховання дітей у закладах для дітей-сиріт та дітей, позбавлених батьківського піклування, спеціальних установах і закладах соціального захисту для дітей незалежно від форми власності;

ведення державної статистики щодо дітей відповідно до законодавства України та міжнародних стандартів;

ведення обліку дітей, які опинились у складних життєвих обставинах, дітей-сиріт та дітей, позбавлених батьківського піклування, усиновлених, влаштованих до прийомних сімей, дитячих будинків сімейного типу та соціально-реабілітаційних центрів (дитячих містечок);

проведення роботи з соціально-правового захисту дітей, запобігання бездоглядності та правопорушенням серед них, із соціально-психологічної реабілітації найбільш уразливих категорій дітей, контроль та координація діяльності служб у справах дітей; 


\section{Адміністративне право}

здійснення $з$ питань, що належать до їх компетенції, координації та методологічного забезпечення діяльності центральних та місцевих органів виконавчої влади, органів місцевого самоврядування стосовно соціального захисту дітей-сиріт, дітей, позбавлених батьківського піклування, осіб із їх числа, а також забезпечення додержання законодавства щодо встановлення опіки i піклування над дітьми-сиротами та дітьми, позбавленими батьківського піклування, їх усиновлення, застосування інших передбачених законодавством форм влаштування дітей;

сприяння розвитку різних форм виховання дітей-сиріт і дітей, позбавлених батьківського піклування [1].

Виходячи 3 вищенаведеного ми можемо класифікувати повноваження служб у справах дітей на три групи:

1) захист прав дітей, які залишилися без піклування батьків;

2) захист прав дітей, що виховуються в сім'ях;

3) організаційна діяльність у сфері охорони та захисту прав дітей.

Діяльність служб у справах дітей здійснюється на принципах: законності; застосування переважно методів виховання i переконання, що передбачають вжиття примусових заходів лише після вичерпання всіх інших заходів впливу на поведінку дітей; гласності, тобто систематичного інформування про стан справ щодо захисту прав дітей, правопорушень серед дітей, роботу центрального органу виконавчої влади, що забезпечує формування державної політики 3 питань сім’ї та дітей, центрального органу виконавчої влади, що реалізує державну політику у сфері сім’і та дітей, органу виконавчої влади Автономної Республіки Крим у сфері сім’ї та дітей, служб у справах дітей, спеціальних установ і закладів соціального захисту для дітей у відкритій державній статистиці, засобах масової інформації; збереження конфіденційності інформації про дітей, які вчинили правопорушення і до яких застосовувалися заходи індивідуальної профілактики; неприпустимості приниження честі і гідності дітей, жорстокого поводження 3 ними [1].
Діяльність досліджуваних суб’єктів публічного права по наданню дітям, їхнім батькам, опікунам чи попечителям допомоги щодо отримання освіти, медичної, правової допомоги, у тому числі у запобіганні домашньому насильству, соціальних послуг, а також діяльність із підбору та підготовці громадян, що висловили бажання стати опікунами чи усиновителями дітей, або прийняти їх у сім'ю на виховання в інших, встановлених законодавством формах, здійснюється у взаємодії з іншими органами публічної адміністрації, медичними та освітніми установами, правоохоронними органами, установами, що надають соціальні послуги, у тому числі для дітей сиріт та дітей що залишились без батьківського піклування. Слід зазначити, що у здійсненні соціального захисту і профілактики правопорушень серед дітей та інших, визначених законом функцій, можуть брати участь підприємства, установи та організації незалежно від форми власності, окремі громадяни, а також інститути громадянського суспільства.

Пріоритетним напрямком діяльності служб у справах дітей є організація профілактичної діяльності (перш за все із соціально уразливими сім'ями) у сфері захисту права дитини на сім'ю, яка передбачає створення умов для своєчасного виявлення і корекції проблем на ранній стадії неблагополуччя, забезпечення дитині в усіх можливих випадках виховання у рідній сім’ї.

Як об'єкти профілактичної та реабілітаційної роботи служб у справах дітей повинні розглядатись не лише діти, що залишились без батьківського піклування, але й діти, які заходяться в становищі, що є загрозою їхньому життю, здоров'ю чи перешкоджає їхньому вихованню. Це діти із сімей, де батьки чи опікуни не виконують своїх обов'язків, встановлених сімейним законодавством, по вихованню, навчанню та утриманню своїх дітей, негативно впливають на їхню поведінку чи жорстоко поводяться 3 ними.

Спрямовуючи свою діяльність на вирішення поставлених стратегічних завдань, а напрям визнання принципу дитиноцентризму є одним з них, держава повинна наділяти відповідні органи влади конкретною достатньою та необхідною компетенцією 
для їх вирішення у сфері забезпечення прав дитини [9, с.206].

Питання правосуб'єктності служб у справах дітей врегульовано пунктом 14 Типового положення про службу у справах дітей районної, районної у містах Києві та Севастополі державної адміністрації, затвердженого постановою Кабінету Міністрів України від 30 серпня 2007 р. №1068, визначаючи їх юридичними особами [4], тож механізм участі цих органів у цивільних правовідносинах є зрозумілим. Однак, вказане Типове положення не є обов'язковим для органів місцевого самоврядування, то служби у справах дітей, що створенні при органах місцевого самоврядування, часто не мають такого статусу. Тож виникає суперечлива ситуація у правозастосовній практиці при визначенні правосуб'єктності цих суб'єктів.

Проте, сам по собі факт відсутності у публічно-правового органу статусу юридичної особи не позбавляє його участі в цивільноправових та адміністративно-правових відносинах. У зв'язку з цим заслуговуе на увагу питання про особливу правоздатність таких органів, відмінну від загальної правоздатності, яка дозволяє виконувати публічно-правові функції. У правовій науці ми зустрічаємо позначення такого виду правоздатності, як надспеціальною, або виключною [10, с.66]. Варто зазначити, що вітчизняна правозастосовна практика не відмовляе у визнанні процесуальної правоздатності органам публічної адміністрації, які не наділені статусом юридичної особи. Служби у справах дітей, які мають спеціальну правосуб'єктність, вчиняють юридично значимі дії 3 метою здійснення своєї компетенції.

Ті служби, які не наділені органами місцевого самоврядування статусом юридичної особи, здійснюють свої публічно-правові функції у сфері ювенальних правовідносин через інші виконавчі органи місцевого самоврядування, зазвичай через виконавчі комітети.

Відповідно до пункту 5 частини 1 статті 26 Закону України «Про місцеве самоврядування в Україні» питання затвердження структури виконавчих органів ради належить до повноважень сільських, селищних, міських рад [5], що, очевидно, має супрово- джуватися наданням відповідним службам статусу юридичної особи. Такий підхід випливає із змісту пункту 5 згаданої Постанови Кабінету Міністрів України, яким органам місцевого самоврядування рекомендовано розробити положення про службу у справах дітей на основі Типового положення про службу у справах дітей обласної, Київської та Севастопольської міської державної адміністрації та Типового положення про службу у справах дітей районної, районної у містах Києві та Севастополі державної адміністрації, тобто з наданням відповідним службам статусу юридичної особи [4].

Констатуючи публічно-правову природу повноважень служб у справах дітей, зауважимо, що вони вступають у правовідносини не від свого власного імені і не у своїх інтеpecax, а є публічно-правовим утворенням державним або муніципальним.

Наявність відомчої вертикалі на усіх організаційних ланках - від місцевої служби у справах дітей до центрального органу виконавчої влади, що реалізує державну політику у сфері усиновлення та захисту прав дітей, вказує на централізовану діяльність цих органів, яка перебуває під пильною увагою і контролем держави, та здійснюється у рамках єдиної національної політики у сфері забезпечення прав дітей з регулятивними і контрольними повноваженнями центрального органу.

\section{Мітература}

1. Про органи і служби у справах дітей та спеціальні установи для дітей : Закон України. URL : https://zakon.rada.gov.ua/laws/ show/20/95-вр\#Text

2. Висновок Комітету Верховної Ради України з питань сім’і, молодіжної політики, спорту та туризму на проект Закону України «Про внесення змін до Закону України «Про органи і служби у справах дітей та спеціальні установи для дітей» (щодо удосконалення правового статусу служб у справах дітей)» №5526 від 12.12.2016. URL : http://w1.c1.rada.gov.ua/pls/zweb2/ webproc4_1?pf3511=60697

3. Пояснювальна записка до проекту Закону України «Про внесення змін до Закону України «Про органи і служби у справах ді- 


\section{Адміністративне право}

тей та спеціальні установи для дітей» (щодо удосконалення правового статусу служб у справах дітей)» №5526 від 12.12.2016. URL : http://w1.c1.rada.gov.ua/pls/zweb2/ webproc4_1?pf3511=60697

4. Про затвердження типових положень про службу у справах дітей : постановою Кабінету Міністрів України від 30 серпня 2007 р. №1068. URL : https://zakon.rada.gov.ua/laws/ show/1068-2007-п\#Text

5. Про місцеве самоврядування : Закон України. URL : https://zakon.rada.gov.ua/laws/ show/280/97-вр\#Text

6. Про добровільне об'єднання територіальних громад : Закон України. URL : https:// zakon.rada.gov.ua/laws/show/157-19\#Text

7. Мельник А.А. Суб'єкти державної політики у сфері захисту прав дітей / Державне управління: удосконалення та розвиток. 2020. №1. URL: http://www.dy.nayka.com.ua/ pdf/1_2020/34.pdf

8. Конституція України : Закон України ; Конституція. URL : https://zakon.rada.gov.ua/ laws/show/254к/96-вр\#Tеxt

9. Навроцький О.О. Забезпечення прав дитини в Україні: теоретичні і практичні засади адміністративно-правового регулювання : дис. докт. юрид. наук ... 12.00.07/ Харківський національний університет імені В.Н. Каразіна, Харків, 2018. 472 с.

10. Голубцов В.Г. Гражданско-правовой статус государственных и муниципальных органов // Журнал российского права. 2006. - №6. - C.58-68.

\section{BODIES AND SERVICES IN CHILDREN'S AFFAIRS IN THE SYSTEM OF PUBLIC ADMINISTRATION BODIES: ISSUES OF LEGAL ENTITY}

The article deals with the public and legal status of juvenile services performing their functions in the field of protection of children's rights in Ukraine. The legal basis for their activities has been analyzed. The main functions and powers of juvenile services have been described. Two models of the Ukrainian juvenile system have been elucidated: in the system of state executive bodies and in the municipal system. The characteristic feature of the public and legal nature of the powers of the juvenile units is that they represent not their own interests.

It has been discovered that the Ukrainian juvenile services which are not registered as a legal entity perform their functions through other executive bodies, usually through executive committees.

There is a vertical from the local juvenile service to the central executive body implementing state policy in the field of adoption and protection of children's rights and it poits at centralization of these functions. Activities in the field of the protection of children's rights are closely monitored and controlled by the state and are carried out within a single national policy with regulatory and supervisory powers of the central body.

Key words: child, children's rights, protection of rights, public administration, juvenile service. 